\title{
Does Peso Depreciation or More Government Debt Affect Aggregate Output? The
} Case of Chile

\author{
Yu Hsing ${ }^{1}$ \\ Antoinette S Phillips ${ }^{2}$ \\ Carl Phillips ${ }^{3}$ \\ Yun-Chen Morgan ${ }^{4}$
}

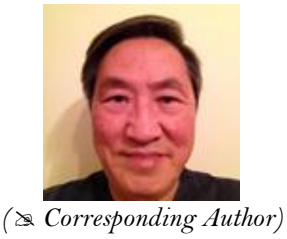

( Corresponding Author

${ }^{1,2, s, 4}$ College of Business Southeastern Louisiana University Hammond, Louisiana 70402 USA.

:Email:yhsing@selu.edu Tel:985-549-2086

'Email:antoinette.phillips@southeastern.eduTel:985-549-2258

'Email:cphillips@selu.edu Tel: 985-549-2086

'Email:ymorgan@selu.edu Tel:985-549-2086

\section{Abstract}

This paper attempts to determine whether real peso depreciation/appreciation or fiscal expansion would be effective in raising output in Chile. Real peso depreciation tends to stimulate exports but raise import costs and domestic inflation. More government debt-financed spending tends to increase aggregate demand but cause the crowding-out effect. Based on an extended IS-MP-AS model (Romer, 2000) incorporating the monetary policy function and the advanced EGARCH process, this study shows that real peso appreciation increased output during 2006.Q1-2011.Q3 whereas real peso depreciation raised output during 2011.Q4-2016.Q4 and that a higher lagged government debt ratio raised output. In addition, a lower U.S. real interest rate, real crude oil price or expected inflation helped increase output. Hence, real peso depreciation or appreciation may increase or reduce output depending upon the development phase, and expansionary fiscal policy is effective. Although more government debt-to-GDP ratio has a positive effect on output, fiscal discipline needs to be pursued as the effect of debt-financed government spending seemed to be leveling off in recent years.

Keywords: Peso depreciation or appreciation, Government debt-to-GDP ratio, World interest rates, Crude oil prices, IS-MP-AS model, Monetary policy function.

JEL Classification: F41; E62.

Citation | Yu Hsing; Antoinette S Phillips; Carl Phillips; Yun-Chen Morgan (2019). Does Peso Depreciation or More Government Debt Affect Aggregate Output? The Case of Chile. Asian Journal of Economics and Empirical Research, 6(1): 70-75. History:

Received: 2 April 2019

Revised: 8 May 2019

Accepted: 10 June 2019

Published: 15 August 2019

Licensed: This work is licensed under a Creative Commons

Attribution 3.0 License $(\mathrm{oc}) \mathbf{E}$.

Publisher: Asian Online Journal Publishing Group
Acknowledgement: All authors contributed to the conception and design of the study.

Funding: This study received no specific financial support.

Competing Interests: The authors declare that they have no conflict of interests.

Transparency: The authors confirm that the manuscript is an honest, accurate, and transparent account of the study was reported; that no vital features of the study have been omitted; and that any discrepancies from the study as planned have been explained.

Ethical: This study follows all ethical practices during writing.

\section{Contents}

1. Introduction

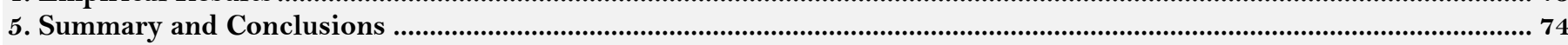

References... 


\section{Contribution of this paper to the literature}

This paper makes several contributions. First, a rigorous theoretical model including comparative static analysis is presented. Second, the advanced EGARCH process is used in empirical work. Third, the binary variable technique is applied to capture any potential structural break of the impact of exchange rate movements on output.

\section{Introduction}

Chile's economy shows both strengths and weaknesses. According to the International Monetary Fund, its real GDP grew 1.59\% in 2016, which was lower than those in 2014 and 2015. The relatively low inflation rate of $3.86 \%$ is consistent with the inflation rate target. The unemployment rate of $6.1 \%$ in 2016 was comparable to its neighboring countries. There have been trade surpluses since 2014. The stock market reached a recent high of 4,927.5 in 2010 and then decreased to 4,151.4 in 2016. The government deficit-to-GDP ratio reached $6.63 \%$ in 2016.Q4. The government debt as a percent of GDP rose from a recent low of 13.09\% in 2008.Q2 to a recent high of $80.06 \%$ in 2016.Q4 because the government engaged in fiscal expansion to save economic downturns triggered by the recent global financial crisis. The Chilean peso depreciated $40.03 \%$ from a recent low of 483.36 pesos per U.S. dollar in 2011 to 676.83 in 2016.

The focus of this paper is to evaluate the effects of real peso depreciation/appreciation and more government debt on aggregate output in Chile based on an advanced macroeconomic model (Romer, 2000). Other related variables will also be considered. Several previous studies (Morley, 1992; Bahmani-Oskooee, 1998; Moreno, 1999; Bahmani-Oskooee et al., 2002; Kim and Ying, 2007; An et al., 2014; Kim et al., 2015) examining the effect of real currency depreciation or appreciation on output apply the traditional Keynesian model and use the money supply to represent monetary policy. Romer (2000) proposes that the LM function can be replaced by the monetary policy function (Taylor, 1993;1999) incorporating inflation targeting. Because Chile has adopted inflation targeting since 1999 (Morandé, 2002) the extended IS-MP-AS model (Romer, 2000) would better capture monetary policy conducted by the Central Bank of Chile.

An analysis of previous studies shows that there are some research gaps for the reasons that (1) some previous studies based on the panel data may not capture unique features of individual countries such as Chile; (2) there was lack of a rigorous macroeconomic model in studying aggregate output; and (3) inflation targeting which has been adopted by the Central Bank of Chile was not incorporated in the model.

This paper makes several contributions. First, a rigorous theoretical model including comparative static analysis is presented. Second, the advanced EGARCH process is used in empirical work. Third, the binary variable technique is applied to capture any potential structural break of the impact of exchange rate movements on output.

\section{Literature Survey}

Real peso depreciation tends to increase exports, import costs and domestic inflation and decrease capital inflows into Chile whereas real peso appreciation is likely to lower exports, import costs and domestic inflation and increase capital inflows into Chile. Hence, the net impact of real depreciation or appreciation is unclear. Several studies including Chile and other related countries in the sample have examined the effect of currency depreciation or devaluation on aggregate output.

Using a sample of 28 LDCs with stabilization programs, Morley (1992) reveals that devaluation hurts output mainly because of the enormous decline in investment expenditures. Using a sample of 27 advanced, Latin American, and Asian countries, Kamin and Klau (1998) show a lack of evidence of the negative impact of devaluation on output in the long run and that there was no major difference in the impact of devaluation among these three groups of countries.

Frenkel (2004) reveals that a $10 \%$ real depreciation would lead to a $5.6 \%$ decline in the unemployment rate two years afterwards. For Chile, a $10 \%$ real depreciation would result in a $8.8 \%$ decrease in the unemployment rate. Rodrik (2008) indicates that real depreciation is expansionary in seven selected developing countries. His results are consistent if different measures of real exchange rates or estimation methods are used.

Mejía-Reyes et al. (2010) report that real depreciation has a severe contractionary effect on aggregate output in Argentina, Chile and Mexico, less severe contractionary effect in Columbia, and an expansionary effect in Brazil and Venezuela. Based on a sample of 17 countries in Latin America and the Caribbean, Mesquita Moreira et al. (2017) show that a $10 \%$ currency depreciation would cause import penetration to decline by $4.1 \%$ to $5.6 \%$.

Whether a higher government debt would affect output depends on whether the crowding-out effect would partially or completely cancel out the positive impact of the debt-financed government spending or whether the debt-to-GDP ratio has reached a turning point or threshold. Barro $(1974 ; 1989)$ argues that the effect of debtfinanced fiscal expansion is neutral over the long run. Cebula (1997;2014a;2014b) shows that more government deficits tend to raise the real interest rate and crowd out private spending. Kumar and Woo (2010) show that if the initial debt-to-GDP ratio rises 1 percentage point, subsequent average GDP growth will decline 0.2 percentage points. The impact is smaller for advanced countries. Reinhart and Rogoff (2010) estimate the threshold to be $90 \%$, meaning that if the debt ratio is above $90 \%$, it would reduce growth and that if the debt ratio is below $90 \%$, its impact on growth is relatively weak. Cecchetti et al. (2011) find the turning point to be $85 \%$. Mencinger et al. (2015) reveal that the turning point is estimated to be $44 \%-45 \%$ for emerging economies and $90 \%-94 \%$ for developed countries. Tran (2018) estimates the debt threshold for 14 emerging countries including Chile during 1999-2016. He finds the turning point for Latin American countries to be $35 \%$ of GDP, which is less than the $40 \%-55 \%$ of GDP for non-Latin American countries. These thresholds suggest that sustainable public finances are more demanding for several Latin American countries facing a higher debt and default risk. Vu et al. (2019) study the relation between economic growth and government debt for eight Latin American countries including Chile during 1990-2015. They show that if the debt ratio is above $35.0 \%$, growth volatility would increase and that if the debt ratio is above $75.0 \%$, growth would decline. Vu et al. (2019) explores the threshold of the government external debt ratio for ten emerging economies including Chile during 2005-2015. The threshold was estimated to be $33.17 \%$ of GDP. He reveals that when the ratio is less than $33.17 \%$, a $1 \%$ increase in the external debt ratio will 
raise the growth rate by $0.056 \%$ and that if the external debt ratio is above $33.17 \%$, a $1 \%$ rise in the ratio will reduce the growth rate by $0.02 \%$.

\section{The Model}

It is postulated that aggregate expenditure is positively affect by real income or GDP, government expenditures and real peso depreciation and negatively influenced by the real lending rate, government tax revenues, and the real crude oil price per barrel, that the real policy interest rate in the monetary policy function is determined by the inflation gap, the output gap, the real exchange rate and the world real interest rate, that the actual inflation rate is determined by the expected inflation rate, the output gap, the real crude oil price per barrel, and the real exchange rate, and that the real lending rate is positively affected the real policy interest rate. We can express an extended IS-MP-AS model (Romer, 2000; Hsing et al., 2019) as:

$$
\begin{gathered}
Y=w(Y, L, G, T, E, O) \\
R=x\left(\pi-\pi^{*}, Y-Y^{*}, E, R^{w}\right) \\
\pi=z\left(\pi^{e}, Y-Y^{*}, O, E\right) \\
L=f(R)
\end{gathered}
$$

where

$\mathrm{Y}=$ real gross domestic product $(\mathrm{GDP})$ in Chile,

$\mathrm{L}=$ the real lending rate,

$\mathrm{G}=$ government expenditures,

$\mathrm{T}=$ government revenues,

$\mathrm{E}=$ the real exchange rate (An increase means real depreciation of the peso.),

$\mathrm{O}=$ the real crude oil price per barrel,

$\mathrm{R}=$ the real policy interest rate of the Central Bank of Chile,

$\pi=$ the actual inflation rate,

$\pi^{*}=$ the target inflation rate,

$Y^{*}=$ potential GDP,

$R^{w}=$ world real interest rate, and

$\pi^{e}=$ the expected inflation rate.

It is assumed that $\pi^{*}$ and $Y^{*}$ are constants over the short term. As government debt is an accumulation of government deficits and as the sovereign debt crisis is a major concern by investors, we replace the government deficit $(\mathrm{G}-\mathrm{T})$ with government $\operatorname{debt}(\mathrm{D})$. Solving for $Y, R$, and $\pi$, we find equilibrium $Y$ as:

$$
\bar{Y}=g\left(E, D, R^{w}, O, \pi^{e}\right)
$$

Figure 1 shows that $\mathrm{Y}$ and $\mathrm{E}$ seemed to have a negative relation during early years and a positive relation during later years. Specifically, real peso appreciation raised Y during 2006.Q1-2011.Q3 whereas real peso depreciation increased Y after 2011.Q3. Real GDP also showed seasonal patterns during the sample period. Thus, an interactive slope binary variable, an intercept binary variable and three seasonal binary variables are included in the estimated regression:

$$
\bar{Y}=h\left(E, E \times B, B, D, R^{w}, O, \pi^{e}, S 2, S 3, S 4\right)
$$

where B = 0 during 2006.Q1 - 2011.Q3, B = 1 during 2011.Q4 - 2016.Q4, and S2, S3 and S4 are seasonal binary variables for the 2 nd, 3rd and 4th quarters. As Chile imports most of its energy needs from abroad, a higher real crude oil price tends to shift short run aggregate supply leftward and cause equilibrium real GDP to decline. Figure 2 suggests that $\mathrm{Y}$ and the debt ratio appeared to have a positive relation during the sample period.

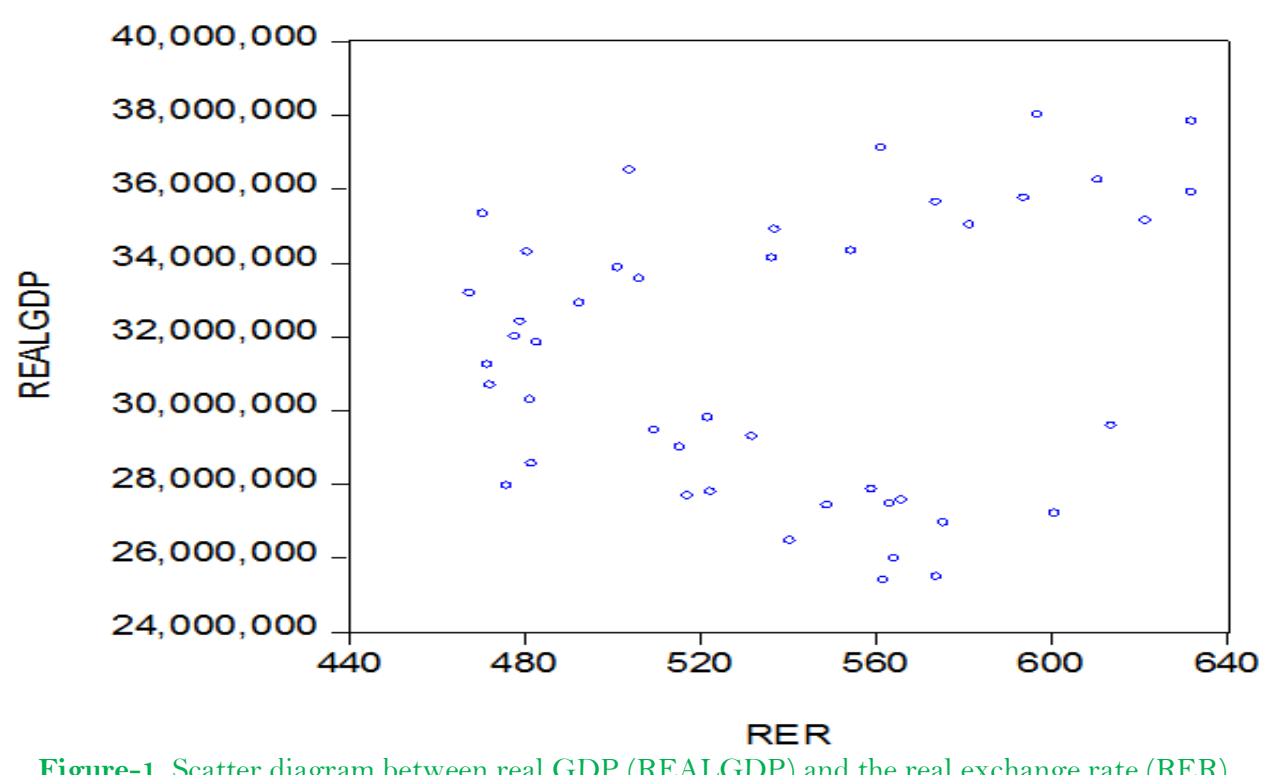

Figure-1. Scatter diagram between real GDP (REALGDP) and the real exchange rate (RER). Source: International Monetary Fund. 


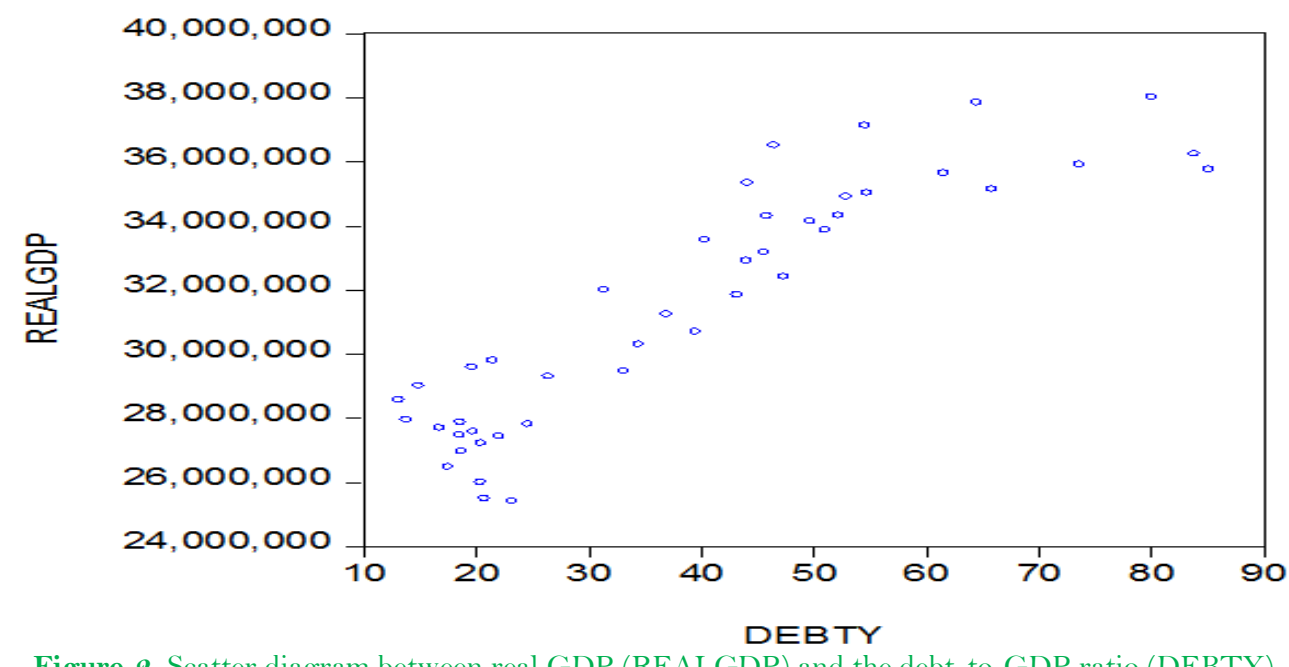

Figure-2. Scatter diagram between real GDP (REALGDP) and the debt-to-GDP ratio (DEBTY). Source: International Monetary Fund.

\section{Empirical Results}

Sources of the data came from the Central Bank of Chile and the International Financial Statistics and the World Economic Outlook published by the International Monetary Fund (2017). Y is expressed in million pesos. E is measured as units of the peso per U.S. dollar times the respective prices in the U.S. and Chile. Hence, an increase in $\mathrm{E}$ means real peso depreciation, and vice versa. The lagged debt ratio is used in order to consider the potential impact lag. $R^{w}$ is represented by U.S. real federal funds rate. $\mathrm{E}$ is represented by the crude oil price per barrel measured in the peso and adjusted by the consumer price index. $\pi^{e}$ is estimated as an average inflation rate in the last four quarters. The sample runs from 2006.Q1 to 2016.Q4. The data for the expected inflation rate before 2006.Q1 are unavailable. The ADF unit root test on the regression residual shows that the test statistic of -3.8166 is less than the critical value of -3.5925 at the $1 \%$ level. Hence, these time series variables are cointegrated.

The estimated regression and related statistics are presented in Table 1. The EGARCH process (Nelson, 1991) is employed. The EGARCH process has fewer restrictions on parameters than the GARCH process by allowing negative values in the parameters and asymmetric positive and negative effects. An analysis of empirical results shows that the estimated coefficients in the conditional variance equation are significant at the $1 \%$ level, suggesting that the EGARCH process is appropriate. The independent variables with significant coefficients can explain $94.72 \%$ of the change in real GDP. Except for the insignificant coefficient of the seasonal binary variable in the third quarter, other estimated parameters are significant at the $1 \%$ or $2.5 \%$ level. Real GDP has a positive relation with real peso appreciation during 2011.Q4-2016.Q4, the lagged debt ratio, and the binary variables representing the second and the fourth quarters and a negative relation with real peso depreciation during 2006.Q1-2011.Q3, the U.S. real federal funds rate, the real crude oil price and the expected inflation rate. The estimated mean absolute percent error of $1.9689 \%$ indicates that the forecast error is expected to be relatively small.

Specifically, a $1 \%$ real appreciation would cause Y to increase by $0.3706 \%$ during 2006.Q1-2011.Q3 whereas a $1 \%$ real depreciation would cause Y to rise by $0.1503 \%$ during $2011 . Q 4-2016 . Q 4$. A $1 \%$ increase in the lagged debt ratio would raise $\mathrm{Y}$ by $0.0488 \%$. A 1 percentage point increase in the U.S. real federal funds rate would cause the $\log$ of $\mathrm{Y}$ to decline by 0.0054 . When the real crude oil price rises $1 \%$, Y would decline $0.0470 \%$.

The base regression represents the first quarter. In the second quarter, the intercept will increase 0.0316 ; and in the fourth quarter, the intercept will increase 0.0624, suggesting that real GDP tends to rise during the holiday season in the fourth quarter.

The positive significant coefficient of the lagged debt ratio is consistent with the threshold of $90 \%$ reported by Reinhart and Rogoff (2010) who indicated that a higher government debt ratio raises economic growth provided that the debt ratio is less than $90 \%$. The data for the debt ratio shows that the highest debt ratio was $68.41 \%$ in 2016.Q3, which is less than $90 \%$.

Table-1. Estimated regression of $\log$ (real GDP) in Chile.

\begin{tabular}{l|c|c|c}
\hline Variable & Coefficient & z-Statistic & Probability \\
\hline C & 19.81669 & 10079.82 & 0.0000 \\
\hline Log(Real exchange rate) & -0.370559 & -23.39766 & 0.0000 \\
\hline Log(Real exchange rate)*Bnary variable & 0.520874 & 8.396828 & 0.0000 \\
\hline Binary variable & -3.109181 & -8.178066 & 0.0000 \\
\hline Log(Lagged debt-to-GDP ratio) & 0.048834 & 6.279259 & 0.0000 \\
\hline U.S. real federal funds rate & -0.005449 & -3.537850 & 0.0004 \\
\hline Log(Real oil price) & -0.046995 & -4.232089 & 0.0000 \\
\hline Expected inflation rate & -0.004164 & -2.258580 & 0.0239 \\
\hline Q2 & 0.031559 & 6.505786 & 0.0000 \\
\hline Q3 & -0.000249 & -0.035955 & 0.9713 \\
\hline Q4 & 0.062362 & 8.949695 & 0.0000 \\
\hline R-squared & 0.947220 & & \\
\hline Adjusted R-squared & 0.931226 & & \\
\hline Akaike information criterion & -4.213700 & & \\
\hline Schwarz criterion & -3.646004 & & \\
\hline Sample period & $2006 . Q 1-2016 . Q 4$ & & \\
\hline Number of observations & 44 & & \\
\hline MAPE & $1.9689 \%$ & & \\
\hline Souree & & & \\
\hline
\end{tabular}

Source: International Monetary Fund and the Central Bank of Chile. 
The negative and significant coefficient of the real federal funds rate indicates that the Central Bank of Chile reacts positively to monetary policy of U.S. Federal Reserve Bank. When the Fed raises the target federal funds rate, the Central Bank of Chile tends to respond and raise its policy interest rate. Other interest rates tend to follow in varying degrees. Higher interest rates in Chile tend to reduce consumption and investment spending, shift aggregate demand leftward, and reduce equilibrium real GDP. The negative and significant coefficient of the real crude oil price tends to shift short-run aggregate supply leftward and cause equilibrium real GDP to decline.

In comparison, the finding that real depreciation was expansionary in Chile during 2011.Q4-2016.Q4 is consistent with Frenkel (2004) and Rodrik (2008) and in contrast with Morley (1992) and Mejía-Reyes et al. (2010). The finding that real appreciation was expansionary in Chile during 2006.Q1-2011.Q3 is different from other studies.

Several other versions were considered. If the government deficit-to-GDP ratio substitutes for the government debt ratio, its estimated coefficient is positive and significant at the $1 \%$ level. If the real federal funds rate is replaced with the U.S. real prime lending rate, its estimated coefficient is negative and significant at the $1 \%$ level and is close to the coefficient of the real federal funds rate. If the simple lagged inflation rate substitutes for the expected inflation rate, its negative coefficient is insignificant at the $10 \%$ level.

\section{Summary and Conclusions}

This study has analyzed the effects of real peso depreciation or appreciation, more government debt and other relevant macroeconomic variables on real GDP in Chile based on an advanced macroeconomic model. Major findings indicate that real peso appreciation raised output during 2006.Q1-2011.Q3 whereas real peso depreciation increased output during 2011.Q4-2016.Q4 and that a higher lagged government debt-to-GDP ratio is expansionary. In addition, a lower U.S. real federal funds rate, real crude oil price or expected inflation rate would help increase output.

These results may have some policy implications. It appears that the relation between real GDP and the real exchange rate had a structural change during the sample period and that the impact of real depreciation or appreciation on real GDP depends on the level of economic development. Hence, the government may need to review their relation periodically in order to determine whether the current relation may be subject to changes. Fiscal expansion measured as a higher lagged debt-to-GDP ratio or deficit-to-GDP ratio is effective in raising output. It suggests that the negative crowding-out effect is relatively small and does not nullify the positive effect of more debt- or deficit-financed spending. The Central Bank of Chile reacts positively to a change in the Federal Reserve's monetary policy. It is anticipated that the Fed may cut its federal funds rate target this year. Therefore, the Central Bank of Chile may need to monitor the decisions made by the Fed to determine whether and how much its policy rate may need to change.

\section{References}

An, L., G. Kim and X. Ren, 2014. Is devaluation expansionary or contractionary: Evidence based on vector autoregression with sign restrictions. Journal of Asian Economics, 34: 27-41.Available at: https://doi.org/10.1016/j.asieco.2014.03.003.

Bahmani-Oskooee, M., 1998. Are devaluations contractionary in LDCs? Journal of Economic Development, 23(1): 131-144.

Bahmani-Oskooee, M., S. Chomsisengphet and M. Kandil, 2002. Are devaluations contractionary in Asia? Journal of Post Keynesian Economics, 25(1): 69-82.

Barro, R.J., 1974. Are government bonds net wealth? Journal of Political Economy, 82(6): 1095-1117.Available at: https://doi.org/10.1086/260266.

Barro, R.J., 1989. The ricardian approach to budget deficits. Journal of Economic Perspectives, 3(2): 37-54.Available at: https://doi.org/10.1257/jep.3.2.37.

Cebula, R.J., 1997. An empirical note on the impact of the federal budget deficit on ex ante real long term interest rates, 1973-1995. Southern Economic Journal, 63: 1094-1099.Available at: https://doi.org/10.2307/1061244.

Cebula, R.J., 2014a. Impact of federal government budget deficits on the longer-term real interest rate in the US: Evidence using annual and quarterly data, 1960-2013. Applied Economics Quarterly, 60(1): 23-40.Available at: https://doi.org/10.3790/aeq.60.1.23.

Cebula, R.J., 2014b. An empirical investigation into the impact of us federal government budget deficits on the real interest rate yield on intermediate-term treasury issues, 1972-2012. Applied Economics, 46(28): 3483-3493.

Cecchetti, S.G., M.S. Mohanty and F. Zampolli, 2011. The real effects of debt. BIS Working Papers No. 352. Basel: Bank for International Settlements.

Frenkel, R., 2004. Real exchange rate and employment in Argentina, Brazil, Chile and Mexico. Centro de Estudios de Estado y Sociedad, Argentina, Working Paper.

Hsing, Y., A.S. Phillips and C. Phillips, 2019. Effects of exchange rate movements on aggregate output in Peru. Southwestern Economic Review, 46(1): 47-56.

International Monetary Fund, 2017. World economic outlook database. Washington, DC.: International Monetrary Fund. Available from http://www.imf.org/en/Publications/WEO/Issues/2017/09/19/world-economic-outlook-october-2017.

Kamin, S.B. and M. Klau, 1998. Some multi-country evidence on the effects of real exchange rates on output. FRB International Finance Discussion Paper No. 611.

Kim, G., L. An and Y. Kim, 2015. Exchange rate, capital flow and output: Developed versus developing economies. Atlantic Economic Journal, 43(2): 195-207.Available at: https://doi.org/10.1007/s1 1293-015-9458-2.

Kim, Y. and Y.-H. Ying, 2007. An empirical assessment of currency devaluation in East Asian countries. Journal of International Money and Finance, 26(2): 265-283.

Kumar, M.S. and J. Woo, 2010. Public debt and growth. IMF Working Paper No. 10/174. Washington, D.C.: IMF.

Mejía-Reyes, P., D.R. Osborn and M. Sensier, 2010. Modelling real exchange rate effects on output performance in Latin America. Applied Economics, 42(19): 2491-2503.Available at: https://doi.org/10.1080/00036840701858117.

Mencinger, J., M. Verbic and A. Aristovnik, 2015. Revisiting the role of public debt in economic growth: The case of OECD countries. MPRA Paper No. 6770.

Mesquita Moreira, M., M.D. Pierola and D. Sánchez-Navarro, 2017. Exchange rate devaluation and import substitution in Latin America and the Caribbean. Inter-American Development Bank, pp: 1-20.

Morandé, F., 2002. A decade of inflation targeting in Chile: Developments, lessons, and challenges. Central Banking, Analysis, and Economic Policies Book Series, 5: 583-626.

Moreno, R., 1999. Depreciation and recessions in East Asia. Economic Review-Federal Reserve Bank of San Francisco, 3: 27-40.

Morley, S.A., 1992. On the effect of devaluation during stabilization programs in LDCs. Review of Economics and Statistics, 74(1): $21-27$.

Nelson, D.B., 1991. Conditional heteroskedasticity in asset returns: A new approach. Econometrica: Journal of the Econometric Society, 59(2): 347-370.

Reinhart, C.M. and K.S. Rogoff, 2010. Debt and growth revisited. MPRA Paper No. 24376. University Library of Munic.

Rodrik, D., 2008. The real exchange rate and economic growth. Brookings Papers on Economic Activity, 2008(Fall): 365-412. 
Romer, D.H., 2000. Keynesian macroeconomics without the LM curve. Journal of Economic Perspectives, 14(2): 149-169.

Taylor, J.B., 1993. Discretion versus policy rules in practice. Carnegie Rochester Conference Series on Public Policy, 39(1): 195-214.

Taylor, J.B., 1999. A historical analysis of monetary policy rules. In Monetary policy rules. Chicago, U.S.: University of Chicago Press. pp: 319-348.

Tran, N., 2018. Debt threshold for fiscal sustainability assessment in emerging economies. Journal of Policy Modeling, 40(2): 375394.Available at: https://doi.org/10.1016/j.jpolmod.2018.01.011.

Vu, Y.H., N.T. Nguyen, T.T. Nguyen and A.T. Pham, 2019. The threshold effect of government's external debt on economic growth in emerging countries. In International Econometric Conference of Vietnam. Springer, Cham. pp: 440-45 1. 